\title{
Marsh Spot Disease and Its Causal Factor, Manganese Deficiency in Plants: A Historical and Prospective Review
}

\author{
Bosen Jia ${ }^{1,2}$, Penner Waldo ${ }^{3}$, Robert Lorne Conner ${ }^{3}$, Ismael Moumen', Nadeem Khan ${ }^{1,2}$, Xuhua \\ $\mathrm{Xia}^{2 *}$, Anfu Hou ${ }^{3 *}$, Frank Mingan You ${ }^{*}$ \\ ${ }^{1}$ Ottawa Research and Development Centre, Agriculture and Agri-Food Canada, Ottawa, Canada \\ ${ }^{2}$ Department of Biology, University of Ottawa, Ottawa, Canada \\ ${ }^{3}$ Morden Research and Development Centre, Agriculture and Agri-Food Canada, Morden, Canada \\ Email: ^frank.you@agr.gc.ca, ^xuhua.xia@uottawa.ca, *anfu.hou@agr.gc.ca
}

How to cite this paper: Jia, B., Waldo, P., Conner, R.L., Moumen, I., Khan, N., Xia, X.H., Hou, A. and You, F.M. (2021) Marsh Spot Disease and Its Causal Factor, Manganese Deficiency in Plants: A Historical and Prospective Review. Agricultural Sciences, 12, 928-948.

https://doi.org/10.4236/as.2021.129060

Received: August 10, 2021

Accepted: September 6, 2021

Published: September 9, 2021

Copyright $\odot 2021$ by author(s) and Scientific Research Publishing Inc. This work is licensed under the Creative Commons Attribution International License (CC BY 4.0).

http://creativecommons.org/licenses/by/4.0/

\begin{abstract}
This review provides an examination of the marsh spot disease in beans and the roles played by its causal factor, manganese $(\mathrm{Mn})$ deficiency. The discovery of the marsh spot disease, its relation with Mn deficiency, and how it can be treated are discussed. Mn serves as a cofactor and a catalyst in various metabolic processes in different cell compartments, such as the oxygen-evolving complex of photosystem II (PSII) or reactive oxygen species scavenging. Some major quantitative trait loci (QTL) and putative candidate genes associated with $\mathrm{Mn}$ content in plants, especially in plant seeds, have been identified. Marsh spot disease in cranberry common bean is controlled by several major genes with significant additive and epistatic effects. They provide valuable clues for QTL candidate gene prediction and an improved understanding of the genetic mechanisms responsible for marsh spot resistance in plants.
\end{abstract}

\section{Keywords}

Marsh Spot, Manganese Deficiency, Quantitative Trait Locus (QTL), Mn Transport, Cranberry Common Bean

\section{Introduction}

Marsh spot is a physiogenic disorder affecting seed quality in peas [1]-[7] and beans [6] [7] [8]. The marsh spot disease was originally described by Dutch scientists as "Kwade harten van de erwten" ("evil heart of the peas") in 1933 [9]. They noted a brown lesion of varying extent in the flat inner surface of one or both cotyledons while still enclosed in the seed coat. Also, he stated that some- 
times this brown lesion was accompanied by partial or entire necrosis of the plumule. Currently, there is renewed interest in marsh spot disease because in susceptible varieties, a brown discoloured spot often occurs at the center of the seeds (Figure 1(C) and Figure 1(D)).

To date, marsh spot disease is thought to be a physiological disorder caused by an Mn deficiency. This article describes the historical development and major progress on marsh spot disease control and its major causal factor-Mn deficiency-related metabolic pathways, gene families, and quantitative trait loci (QTL) and their predicted candidate genes.

\section{Marsh Spot Disease and Its Causal Factor}

\subsection{Symptoms and Signs of Marsh Spot Disease}

In 1944, several pulse species, including peas (Pisum sativum), broad beans ( $V i$ cia faba), runner beans (Phaseolus coccineus), French (dwarf) beans ( $P$. vulgaris) and Phaseolus vulgaris (var. Masterpiece) were raised at Long Ashton, England, in manganese $(\mathrm{Mn})$-deficient sand cultures, using a refined pot-culture procedure/way, and the pods were left on the plants until they dried before harvesting [8]. Severe marsh spots in peas and mild to severe marsh spot symptoms in broad beans and runner beans were observed. The cotyledon center was sunken, brown, and pithy. Also, the embryos in beans often exhibited a browning of the plumule, which also was observed in peas. However, the dwarf beans did not
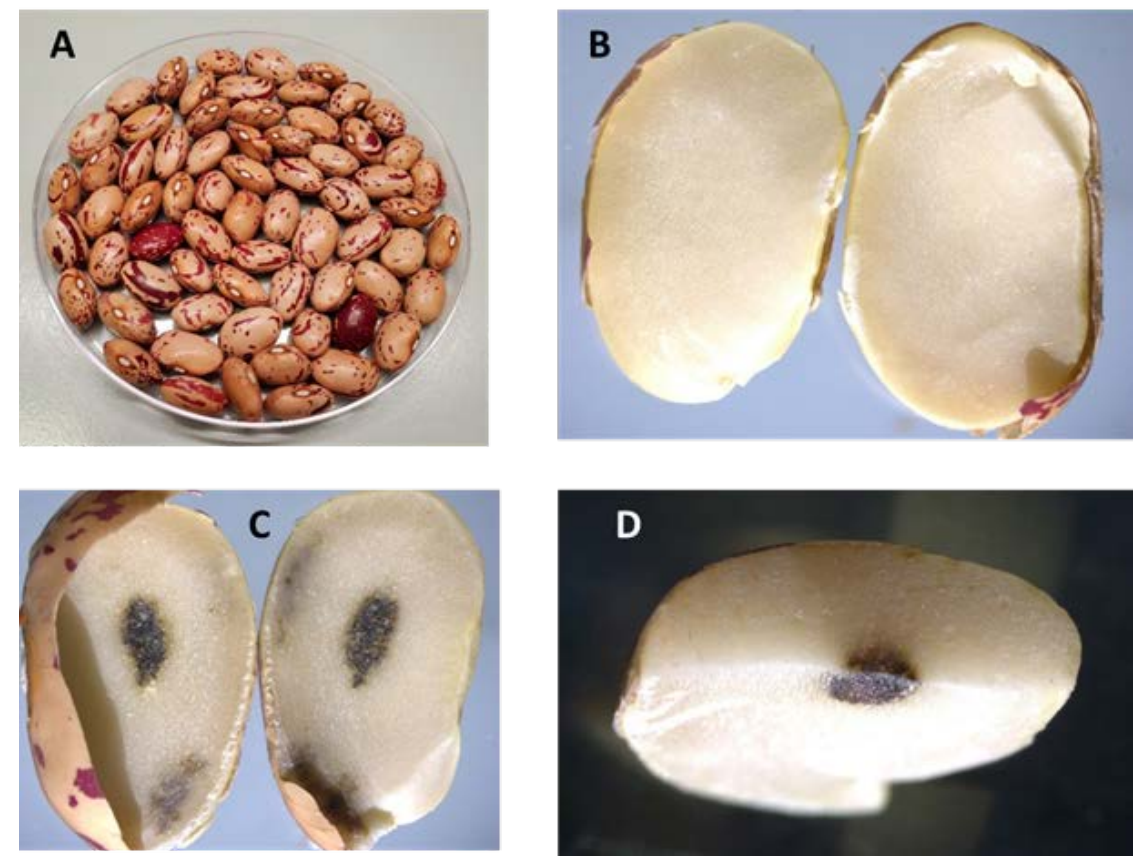

Figure 1. Cranberry common bean seeds and the symptoms of marsh spot disease. (A) The exterior seed color of cranberry market class (cultivar Messina). (B) Marsh spot-free split seed of the resistant cranberry common bean cultivar Cran09. (C) Split seed with a high marsh spot rating of the susceptible cranberry common bean cultivar Messina. (D) Cross section of a seed with marsh spot disease showing the depth of the spot. 
show any symptoms of marsh spot [8]. At the same time, the symptoms on leaves which were caused by $\mathrm{Mn}$ deficiency were extremely severe in dwarf beans, while in pea and broad bean the leaf symptoms were not outstanding. One explanation for this observation was that pea and broad bean $(0.5 \mathrm{~m}-2 \mathrm{~m}$ and $0.3 \mathrm{~m}-1.2 \mathrm{~m}$ in plant height, respectively) were taller than dwarf bean $(0.1$ $\mathrm{m}-0.3 \mathrm{~m}$ in plant height) and usually had a longer growth period (6 - 7 months and 8 months, respectively). Taller plants have to cope with a permanently fluctuating availability of soil nutrients, both in space and time [10]. As Mn can only be easily transported by xylem, but hardly in the phloem [11], so Mn is difficult to remobilize in plants. Mn accumulated in the old leaves cannot be remobilized to other tissues in large amounts. Thus, most of limited Mn may present in old tissues in pea and broad bean with longer growth period rather than in the seeds.

The size of the marsh spots in the seeds varied. Some spots were quite small, while others expanded to the edge of the seeds. The plumule could be altered when the discoloration was great. However, it was unusual to see any damage to the plumule. Broad cotyledon necrosis predisposed the seeds to attack by secondary bacterial or fungal organisms, making the damage worse. Sometimes there was no internal visual discoloration, but only a denseness of the central tissue [12].

A discoloured spot in seeds was usually observed at the center of the adaxial surface of each endosperm's cotyledon. Under a microscope, the discoloured area seems to be caused by the cell death underneath the cotyledons' skin. The starch stored in those cells was transformed or replaced by a brown substance, which eventually discoloured the cell walls and invaded the intercellular spaces [2].

The seed germination rate can be severely reduced by marsh spot. For pea seeds with more than a $20 \%$ damaged area, the germination rate was much lower than that of normal seeds [13]. For instance, when both cotyledons had large specks with the same conditions on the plumule, the seeds had difficulty germinating [13].

\subsection{Measurement of the Marsh Spot Resistance in Cranberry Common Bean}

The resistance or susceptibility to marsh spot of cranberry bean seeds can be measured based on the size of the marsh spots in the seeds. The seeds are split in half using a custom-made cereal head threshing board and rubbing block (Figure 2(A)) [14]. Most seeds are quite easy to break apart. But for more challenging seeds, a carpenter's knife or a large \#4 scalpel with a \#21 blade can be used (Figure 2(B)). Then an imaging tool, a Zeiss stereoscope, Stemi 508, with an Axiocam 105, is used for the close-up photos and measurement of the size of marsh spots. Then, the marsh spot severity ratings are scored on a scale of $0-5$ based on the width of marsh spots [14] (Figure 2(C)). A score 0 indicates no symptoms. A marsh spot resistance index (MSRI) to present severity is calculated using the following formula: 

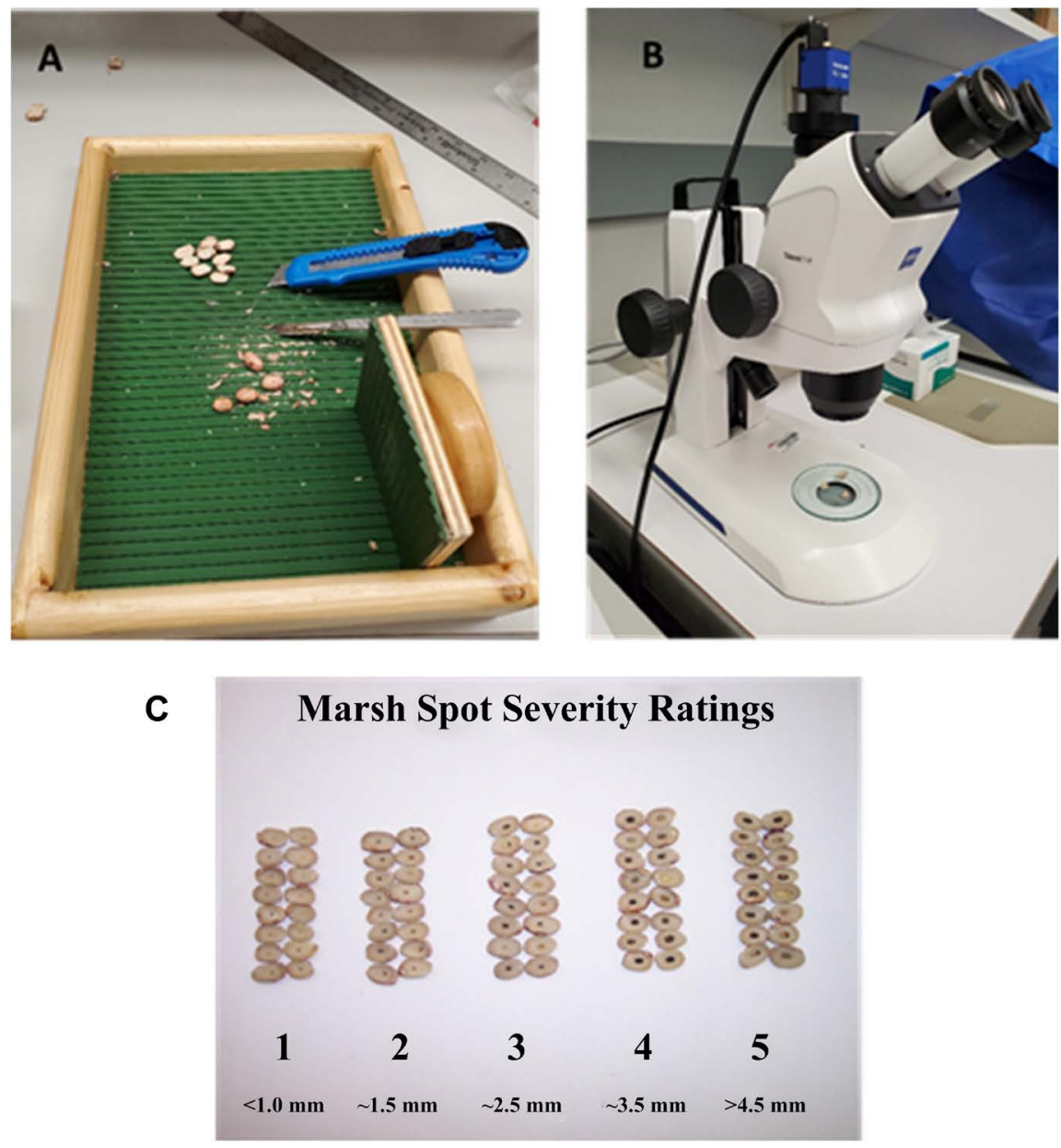

Figure 2. A marsh sport severity scoring system for cranberry common bean. (A) Seed splitting tools to shear the cotyledon halves. Knives can have also been used. (B) Steroscope for the close-up photos. (C) Marsh spot severity ratings of seeds of cranberry common bean [14]. The numbers from 1 to 5 , which indicate the marsh spot severity of the seeds, are related to the size of the discoloured brown spot at the center [14].

$$
M S R I=\frac{\sum_{i=0}^{n}(\text { number of seeds with a rating with } 0-5 \text { scale } \times \text { the rating value })}{\text { Total number of seeds }}
$$

where $n$ represents the total number of seeds with specific ratings of 0 to 5 [14].

\subsection{Causal Factor of Marsh Spot Disease: Mn Deficiency}

Initially, brown spot symptoms were believed to be caused by microorganisms, so scientists attributed marsh spot to a bacterial infection. However, they failed to isolate any pathogens from peas. Lacey [5] performed an examination to detect bacteria on the cotyledons of seeds with marsh spot symptoms and inoculated healthy plants using the tissues from marsh spot seeds. However, no marsh spot symptoms developed when the inoculated seeds were planted under the same soil conditions. Also, no bacteria were extracted from marsh spot seeds, indicating that the marsh spot was not incited by a pathogen. Later, Pethybridge 
[15] observed that marsh spots occurred in a plot of peas growing alongside oats affected with grey speck. This observation made him consider whether marsh spots in peas were also affected by an Mn deficiency like a grey speck in oats. Furthermore, Furneaux and Glasscock [12] using a colorimetric method discovered that pea seeds with marsh spot symptoms had a lower Mn content than healthy ones. Then, Heintze [4] used a hydroponic method for growing peas and investigated several traits (i.e., root length, flowering time, and seed formation) at different concentrations of $\mathrm{Mn}^{2+}$. Consequently, it was confirmed that the marsh spot was caused by an Mn deficiency [4].

Heintze [4] grew peas in a sand-bentonite culture medium and showed that if no $\mathrm{Mn}$ was added to the culture medium, $12 \%-15 \%$ of the seeds exhibited symptoms of marsh spot, but no seeds had the marsh spot symptoms if Mn was added to the medium. He also designed experiments in which zinc or molybdenum was added into a water culture with a low Mn concentration to investigate their importance. The results showed that additions of sodium molybdate and zinc sulphate to Mn deficient soils generally increased the incidence of marsh spot in peas, but not in the soil with an ample supply of $\mathrm{Mn}$. Those results also indicated that sodium molybdate affects Mn uptake processes within the plants and possibly suppressed Mn uptake [2].

Samuel and Piper [16] stated that no other obvious Mn deficiency symptoms were observed in peas with marsh spot seeds during their vegetative growth. The marsh spot symptoms could only be detected in mature seeds. Therefore, marsh spot may be caused by a partial Mn deficiency as a severe deficiency led to the plants' death before seed development [16]. To assess this theory, the effects of different quantities of $\mathrm{Mn}$ on the growth of peas were examined using a water-culture technique that enabled the strict control of Mn concentrations available to the plants [3]. When no Mn was added to water culture, specks occurred on the young leaves, and the growing tips often were dead. Most plants did not reach the flowering stage. When sufficient $\mathrm{Mn}$ was supplied in the nutrient solutions, plants could grow normally and produce seeds. While small amounts of $\mathrm{Mn}$ that were insufficient for normal growth requirements still enabled the seeds to form, but the seeds showed marsh spot symptoms, and the size of the spots were greatest at the lower Mn concentrations [3].

Moreover, at low concentrations of $\mathrm{Mn}$, marsh spot symptoms more frequently occurred on the late-maturing seeds. Following the application of sufficient $\mathrm{Mn}$ to the nutrient solutions, marsh spot symptoms did not occur on newly developed seeds, even though specks remained on earlier formed seeds. This confirmed that the marsh spot might result from a partial deficiency of Mn. Although this disease did not affect pea reproduction itself, the quality of seeds produced was reduced [2].

However, Moraghan and Grafton [17] noted that cranberry bean ( $P$. vulgaris) cultivars may display differences in susceptibility to marsh spot. Four cranberry bean cultivars were planted in two soil types (i.e., acid and calcareous) in North 
Dakota; although whole seed $\mathrm{Mn}$ content was relatively high in all cultivars, marsh spot symptoms were still observed. It also was noted that the application of manganese sulfate did not decrease the incidence of seeds with marsh spot. This indicated that marsh spot might also be affected by other micronutrients [17].

\subsection{Treatments for Controlling Marsh Spot Disease}

$\mathrm{Mn}$ treatments can be applied to reduce plant $\mathrm{Mn}$ deficiency symptoms. In some fenland and marsh areas, where the marsh spot disorder most widely occurs, Mn treatments are considered as a vital routine step [1]. Most growers realize the importance of spraying $\mathrm{Mn}$ treatments at flowering time to avoid marsh spot symptoms in the seeds [18]. However, the manganese sulphate's application to prevent Mn deficiency in peas is still limited because unclear symptoms during vegetative and reproductive growth do not allow the farmer to determine whether the supplementary $\mathrm{Mn}$ is required [2]. An additional issue that warrants consideration is the extent of crop damage resulting from the use of spraying machines or chemical fertilizers. Another important factor is the careful application of lime, particularly on black fen and neutral or slightly acid soils. The shell marl forms of black peat have shown to be associated with high incidences of severe marsh spot symptoms.

Manganese sulphate sprays help control marsh spot disease in peas and increase seed weight and yield. The seed yields of the two peas varieties, Jumboka and Zelka, were significantly increased from 345 - $350 \mathrm{~g}$ to 417 - $455 \mathrm{~g}$ per plot [18] in response to sprays of $\mathrm{MnSO}_{4}$. Increases up to $81 \%$ in extra seed yield in peas were obtained following sprays with manganese salts' solutions [19]. These results demonstrate that the supplement of $\mathrm{Mn}$ can improve the seed production.

However, the application of manganese salts may delay ripening. For instance, manganese sulphate's application to peas at flowering time delayed maturity by ten days compared to the untreated plots [12].

\section{Overview of the Current State of Knowledge}

\subsection{Knowledge from a Physiological Point of View}

In one of the photosynthetic pathways, photosystem II (PSII), Mn is a critical element in the oxygen-evolving complex metalloenzyme cluster [20]. The confirmed formula $\mathrm{Mn}_{4} \mathrm{Ca}_{1} \mathrm{O}_{\mathrm{x}} \mathrm{Cl}_{1-2}\left(\mathrm{HCO}_{3}\right)_{y}$, which is known as the tetra-nuclear $\mathrm{Mn}$ cluster, is bound by the reaction center protein PsbA (D1) of the OEC [21]. Most of the Mn elements present in plants are involved in this process. Thus, Mn deficiency will lead to a decreased amount of the Mn-complex in the PSII core. For this reason, low concentrations of Mn will make PSII complex unstable and they may even disintegrate, eventually resulting in a low photosynthetic rate. Since leaves are almost the only source of organic matter for seed production, decreases in the amounts of photosynthate in the leaves would have a large nega- 
tive impact on seed production and finally lead to the development of marsh spot symptoms. Moreover, because of low mobilization of $\mathrm{Mn}$ in the phloem, usually the new leaves first turn yellow while the old ones remain green [21].

In addition to PSII in photosynthesis, the detoxification of reactive oxygen species (ROS) also requires Mn. One of the key characteristics of plant mitochondria is that when mitochondria respire, the redox centers will inevitably produce ROS to regulate plant metabolism and growth. Especially when plants are undergoing abiotic or biotic stress, this process will be more active [22]. Also, ROS is involved in the regulation of nuclear transcription.

However, ROS concentration has to be rigorously controlled by the antioxidant system, since positive redox may threaten the cellular machinery. The fragile cytoplasm and cell membranes can be disrupted by superoxides produced by ROS. In a plants cell, superoxide dismutase (SOD) is a unique enzyme that assists cells in the dismutation of superoxide radicals of $\mathrm{H}_{2} \mathrm{O}_{2}$ and $\mathrm{O}_{2}$. A high concentration of $\mathrm{Mn}^{2+}$ was observed in the complexes with amino acids, peptides, nucleotides, and carbohydrates in the mitochondria. Mn is a cofactor of MnSOD, an important enzyme that is produced by the mitochondria, which produces $\mathrm{H}_{2} \mathrm{O}_{2}$ and $\mathrm{O}_{2}$ [23]. Those $\mathrm{Mn}$ complexes are efficient scavengers of $\mathrm{O}_{2}^{-}$and $\mathrm{OH}$. When plants are under oxidative stress, $\mathrm{Mn}^{2+}$ also can substitute for iron in some proteins to alleviate iron toxicity. Furthermore, one of the oxalate oxidases that are involved in the oxidation of oxalic acid is also an Mn-dependent enzyme.

Reduced MnSOD often alters the mitochondrial redox equilibrium and plant growth. Moreover, the oxidizing reaction is relatively intense during seed formation and germination with lots of $\mathrm{O}_{2}^{-}$being produced. Therefore, a lack of $\mathrm{Mn}$ may result in necrosis, an oxidative stress symptom, which is first manifested as brown specks between the veins caused by an overaccumulation of ROS within the chloroplasts [23].

Young leaves display the first symptoms of Mn deficiency. Pale mottled leaves in addition to the interveinal chlorosis are considered as the main symptoms of this deficiency [24]. If a severe Mn deficiency occurs, leaves display gray speck symptoms, that appear as brownish, necrotic spots. Brown spots also occur within the plant seeds, i.e., marsh spot symptoms. Broadley, et al. [25] reported that if the free oxygen radicals are high in chloroplasts, then they will reduce MnSOD activity, which ultimately results in the formation of necrotic spots.

Besides, Mn-dependent enzymes, Mn also plays a major role in the synthesis pathways of isoprenoid, lignin, and cuticular waxes in leaves [26] [27] [28]. Isoprenoid exists widely in plants, including diversiform primary and secondary metabolites such as carotene and hormones. Those components are closely associated with the cell membrane, electron transfer, and photoprotection. When plants lack Mn, those biochemical processes also will be affected. Mn-deficiency also leads to a low concentration of lignin, especially in the roots. Therefore, maldeveloped roots often predispose plants to pathogens and weed competition, 
which subsequently results in lower productivity.

These Mn-dependent components have special functions in plant growth and development; the lack of $\mathrm{Mn}$ or production of these components may lead to physiological diseases in plants, such as marsh spot.

Mn deficiency often occurs in plants growing in soils with low available Mn and in highly leached tropical soils. It is also common in high $\mathrm{pH}$ soils having free carbonates, especially those with a high organic matter content [25]. In Mn-deficient plants, dry matter production [29], net photosynthesis, and chlorophyll content can decrease quickly [30]. In contrast, rates of respiration and transpiration remain unaltered [29]. Mn-deficient plants are more sensitive to damage by freezing temperatures and a range of soil-borne, root-rotting fungal diseases and need twice as long to enter the boot stage than Mn-sufficient crops. A reduction in the number of kernels and grain yield in Mn-deficient plants is probably due to a mixture of low pollen fertility and a reduced carbohydrate supply for grain filling. Leaves of plants with low Mn tend to be yellow, especially the young leaves. When $\mathrm{Mn}$ deficiency is relatively severe, leaves will curl up and wilt. Sometimes some brown spots occur on the leaves. Mn deficiency is known to reduce yield and overall plant health in soybean (Glycine max) [2].

\subsection{Knowledge from a Genetic Point of View}

\subsubsection{Mn Uptake in Some Model Plants and Related Gene Families}

As previously mentioned, $\mathrm{Mn}^{2+}$ is only available in a metal form to plants. Most of the proteins responsible for the transport of Mn across membranes are not only responsible for this metal, but also other cations, especially divalent cations such as $\mathrm{Fe}^{2+}, \mathrm{Zn}^{2+}, \mathrm{Cu}^{2+}, \mathrm{Cd}^{2+}, \mathrm{Ca}^{2+}, \mathrm{Co}^{2+}$, and $\mathrm{Ni}^{2+}$. Thus, sometimes the expression of genes that code for these protein families are regulated by the concentrations of other cations. It may be that the genes have diverse regulatory factor domains for different cations. More investigation, including the modification of specificity, is required to understand the low specificity in physiological relevance. For example, in the $\mathrm{Mn} / \mathrm{Fe}$ transporter AtMTP8, Fe transport activity can be disrupted by inducing mutations in those Fe-binding domains with no impact on its $\mathrm{Mn}^{2+}$ transport capability [31].

The ZIP transporters commonly occur in bacteria, fungi, plants, and animals and are expected to be associated with $\mathrm{Fe}^{2+}, \mathrm{Zn}^{2+}, \mathrm{Cd}^{2+}, \mathrm{Co}^{2+}, \mathrm{Cu}^{2+}$, and $\mathrm{Mn}^{2+}$ transport. They have eight transmembrane domains (TMD) with extracellular $\mathrm{N}$ - and C-termini and a cytosolic histidine-rich loop. YSL transporters are linked to the oligopeptide transporter (OPT) family and occur only in plants, bacteria, fungi, and archaea. Members of the YSL family are predicted to transport metals $\left(\mathrm{Mn}^{2+}, \mathrm{Zn}^{2+}, \mathrm{Cu}^{2+}, \mathrm{Ni}^{2+}, \mathrm{Cd}^{2+}, \mathrm{Fe}^{2+}\right)$ complexed to non-proteinogenic amino acids, such as nicotinamide (NA) or phytosiderophores [32] [33].

The cation diffusion facilitator (CDF) family, which includes metal transport proteins (MTP) in higher plants [34] [35] is common among plant organisms. Most CDFs are $\mathrm{Metal}^{2+} / \mathrm{H}^{+}\left(\mathrm{K}^{+}\right)$antiporters and mediate the efflux of $\mathrm{Zn}^{2+}, \mathrm{Co}^{2+}$, 
$\mathrm{Fe}^{2+}, \mathrm{Cd}^{2+}, \mathrm{Ni}^{2+}$, and/or $\mathrm{Mn}^{2+}$. The majority have six TMDs with histidine-rich regions at their cytosolic $\mathrm{N}$ - and/or C-terminus and additionally between the 4 th and 5th TMD. Based on their phylogenetic relationships, the CDF family can be classified into the three major metal transporter subgroups that include $\mathrm{Zn}$-CDFs, $\mathrm{Zn} / \mathrm{Fe}-\mathrm{CDF}$, and Mn-CDFs [36].

Other gene families such as BICAT (Bivalent Cation Transporter) [20], CaCA $\left(\mathrm{Ca}^{2+} /\right.$ cation antiporter) [37], VIT (the vacuolar iron transporter) [38] also are present in most plants. BICAT joins in the transport of $\mathrm{Mn}$ and $\mathrm{Ca}$. Cation/ $\mathrm{Ca}^{2+}$ exchanger (CCX) and the $\mathrm{H}^{+}$/cation exchanger (CAX) are two important subfamilies in CaCA, which have been observed to be related to Mn transport. VIT transports carry both $\mathrm{Fe}^{2+}$ and $\mathrm{Mn}^{2+}$, but their actual functions are still unclear. P2A-type $\mathrm{Ca}^{2+}$-ATPases, which belong to plant P-type $\mathrm{Ca}^{2+}$-ATPases, also play a role in $\mathrm{Mn}^{2+}$ transport. Some important gene families reported in seed development are listed in Table 1.

\subsubsection{Gene Families of Mn Transport among Plant Tissues}

Since Mn was identified as a factor that can lead to marsh spot development, the process of Mn transportation from soil and finally into the plant cell should be examined. The first step in a plant's utilization of $\mathrm{Mn}$ is its absorption from the soil by the roots. Mn absorption occurs using an active transport system located in the epidermal root cells. It is then carried as the divalent cation of $\mathrm{Mn}^{2+}$ within the plants [46]. They are two main phases in the Mn absorption process. The initial, rapid uptake phase is reversible and does not require any energy consumption, $\mathrm{Mn}^{2+}$ and $\mathrm{Ca}^{2+}$ or other cations can be freely interchanged in the rhizosphere. $\mathrm{Mn}^{2+}$ is absorbed by the negatively charged cell wall constituents in the root-cell apoplastic spaces. In the second phase, which is not rapid, the $\mathrm{Mn}^{2+}$

Table 1. Mn transport gene families involved in seed development.

\begin{tabular}{|c|c|c|c|c|}
\hline Family & Species & Subcellular & Gene expression response & Reference \\
\hline \multicolumn{5}{|l|}{$\mathrm{CaCA}$} \\
\hline OsCAX1a & Rice & Tonoplast & & Kamiya, et al. [40] \\
\hline OsCAX3 & Rice & & & Kamiya, et al. [40] \\
\hline \multicolumn{5}{|l|}{ CDF/MTP } \\
\hline AtMTP8 & Arabidopsis & Tonoplast & Up-regulated by $\mathrm{Mn}-\mathrm{Fe}$ & Eroglu, et al. [41] \\
\hline AtNRAMP3 & Arabidopsis & Tonoplast & Up-regulated by Fe & Thomine, et al. [42] \\
\hline AtNRAMP4 & Arabidopsis & Tonoplast & Up-regulated by Fe & Lanquar, et al. [43] \\
\hline OsYSL2 & Rice & Plasma membrane & Up-regulated by Fe, down-regulated by Mn & Koike, et al. [44] \\
\hline \multicolumn{5}{|l|}{ ZIP } \\
\hline HVlRT1 & Barley & Plasma membrane & Up-regulated by $\mathrm{Fe}$ & Pedas, et al. [45] \\
\hline
\end{tabular}


exchange becomes more difficult. Plant metabolism influences the absorption in the symplast [47], although the mechanisms are not precisely known [48]. The speed of ion carriers and channels that are involved in $\mathrm{Mn}^{2+}$ transportation vary dramatically. The amount of transported molecules through the plasma membrane can vary from thousands to millions [48].

The distribution of $\mathrm{Mn}$ from the root cells in a plant requires primary movement in the xylem and transfer from the xylem to the phloem. The transpiration stream leads to xylem transfer from roots to the above-ground components of the plants. The phloem has membrane proteins that control cation movement [46]. Mn moves slowly in the phloem. Mn redistribution often varies among plant species and with the growth stage. For example, insufficient $\mathrm{Mn}$ transport from roots to the seeds has been observed in wheat (Triticum aestivium) at maturity [49]. The importance of the xylem in the Mn transport should be emphasized due to the low Mn mobility in the phloem.

Some proteins involved in Mn uptake by the roots have been studied in model plants such as Arabidopsis, rice (Oryza sativa) and barley (Hordeum vulgare) [46] [50] [51]. Natural resistance-associated macrophage protein (NRAMP) families are members of the major proteins implicated in Mn transportation from the root to the stem. Transporters that participate in Mn uptake, xylem loading, and root-to-shoot translocation have been more thoroughly studied in rice (Oryza sativa) compared to other plant species [52]. OsNRAMP5, the first $\mathrm{Mn}^{2+}$ transporter gene identified in rice, is involved in the $\mathrm{Mn}^{2+}$ uptake and translocation [51]. It was localized in the plasma membrane on the distal side of cells in the root and endodermis and is responsible for the initial absorption of $\mathrm{Mn}^{2+}$ from a soil solution. In addition, in Arabidopsis, AtNRAMP1, which is a homolog of OSNRAMP5 in rice, also mediated Mn uptake [53]. The expression of AtNRAMP1 in Arabidopsis is moderately upregulated by the lack of Mn [53]. Recently in barley, $H_{V N R A M P 5}$, a homolog of rice OsNRAMP5, was reported to be involved in Mn uptake and was observed in the plasma membrane of the epidermal cells [54]. The expression of HVNRAMP5 was up-regulated by a Fe limitation rather than an Mn deficiency. In various root structures, Mn uptake was influenced by the environment (i.e., climate and soil type), which resulted in different responses to variations in Mn availability among species [55]. Fe limitation may also explain why in a previous study, marsh spot was not clearly associated with Mn deficiency [17]. Compared to OsNRAMP5, AtNRAMP1 and $H_{V N R A M P 5}$, which were localized in the epidermis, OsNRAMP3 was responsible for the transfer of $\mathrm{Mn}^{2+}$ from the xylem to the phloem at the basal node of rice [56]. However, at high $\mathrm{Mn}$ availability, it also was distributed to mature tissues. Therefore, in rice nodes, OsNRAMP3 functions as a switch for Mn distribution, whereby the protein is activated or deactivated in response to fluctuating $\mathrm{Mn}$ concentrations. When $\mathrm{Mn}$ was limited, there would be more Mn transferred to the upper node/panicle through the phloem under the control of OsNRAMP3 [56]. A homolog of OSNRAMP3 also may have an influence on Mn transpiration 
flow to plant seeds.

The transporter gene OSMTP9, located next to OSNRAMP5, is responsible for the $\mathrm{Mn}^{2+}$ uptake and translocation [57]. Subsequently, OsMTP9 was located in the plasma membrane on the proximal side of those rice cell layers, where it arbitrates the export of $\mathrm{Mn}^{2+}$ into the stele [51]. $\mathrm{Mn}^{2+}$ uptake and root-to-shoot translocation were highly diminished when either OsMTP9 or OsNRAMP5 was knocked out, which indicates that those transporter genes were responsible for moving $\mathrm{Mn}^{2+}$ from the soil to the xylem. Radial movement of $\mathrm{Mn}^{2+}$ was carried out by polarly localized transporters at both the exodermis and the endodermis, which provided a unidirectional flow of $\mathrm{Mn}$ from the soil to the stele. Thus, in soils within the same concentration of $\mathrm{Mn}$, total amounts of absorbed Mn would be significantly different in the presence of OsNRAMP5, OSMTP9 and their homologs [51].

Moreover, Yellow Stripe-Like (YSL) transporters were also involved in Mn uptake. In the long-distance transport and distribution of $\mathrm{Mn}$ in rice, it may be conveyed as $\mathrm{Mn}^{2+}-\mathrm{Na}^{+}$as well as an Fe-Na complex [44]. Since OSYSL2 also was observed in developing seeds, $\mathrm{Mn}$ accumulation in seeds was regulated by OsYSL2. In Arabidopsis, the YSL family also was reported to contribute to Mn translocation. Decreases in Mn concentration have been observed in leaves during Arabidopsis senescence, while in ysl1ys 3 double mutant plants the Mn concentration remained at the same level [58]. Hence, both AtYSL1 and AtYSL3 are thought to be the $\mathrm{Mn}^{2+}-\mathrm{Na}^{+}$transporters. In the absence of AtYSL1 and AtYSL3, Mn could not be transported to new tissues from ageing leaves.

Unlike NRAMP, two members of the ZIP (Zrt and Irt-like protein) family, AtZIP1 and AtZIP2, were not affected by Mn deficiency [59]. Those two genes were involved in the transport of $\mathrm{Mn}$ in root stellar cells. Both of them were expressed in the root stele, but at different subcellular locations. AtZIP1 was present in the tonoplast and took part in remobilizing $\mathrm{Mn}$ from the vacuoles to the cytoplasm. In contrast, AtZIP2 was positioned in the plasma membrane and may regulate $\mathrm{Mn}$ uptake into root stellar cells. In barley, $H_{V I R T 1}$, which also belongs to the ZIP family, was involved in Mn uptake, and its expression was moderately induced by Mn deficiency [45].

\subsubsection{Proteins Families Involved in Mn Transport among Subcellular Components}

After Mn has been transported into plant tissues and enters a plant cell, $\mathrm{Mn}$ is further transferred to provide an adequate quantity to the Mn dependent targets or for storage. Mn was reported in all organelles, including ER, Golgi apparatus, mitochondria, plastids, and peroxisomes, where it performs specific cellular functions as previously mentioned.

Mn-CDF comprises a subgroup of the CDF/MTP families that participate in the sequestering of Mn into the vacuoles. AtMTP8, one of the members of 
Mn-CDF, plays an important role during seed development. AtMTP8 has been identified as a transporter of $\mathrm{Fe}$ and $\mathrm{Mn}$ [31]. An analysis of metal localization in embryos by XRF tomography showed that AtMTP8 is responsible for the specific accumulation of $\mathrm{Mn}$ in the subepidermal cells on the abaxial side of the cotyledons and cortical cells of the hypocotyl, which were very close to the location of marsh spot symptoms [31]. A similar distribution of Fe and Mn in all the cell types of Arabidopsis embryos was observed in an $m t p 8$ vit 1 double mutant. These results indicate that $\mathrm{Mn}$ and $\mathrm{Fe}$ allocation are determined by the two primary transporter genes, AtMTP8, and AtVIT1 [31].

The VIT gene AtVIT1, also was identified as a vacuolar Fe/Mn transporter. In Arabidopsis, AtVIT1 was involved in the allocation of Fe to perivascular strands of seed embryos. When either VIT1 or MTP8 was silenced, the location where $\mathrm{Mn}$ and Fe accumulated dramatically changed. Fe or Mn was not accumulated in specific cell types, but distributed among all cell types in the seeds. Those mutants later showed symptoms of micronutrient deficiencies [31].

In rice, when OsVIT1 and OsVIT2 were ectopically expressed in yeast, a $\mathrm{Fe}^{2+}$ and a $\mathrm{Zn}^{2+}$ sensitive strain showed increased accumulations of $\mathrm{Fe}^{2+}, \mathrm{Zn}^{2+}$ and $\mathrm{Mn}^{2+}$ in the vacuole. Similar to AtVIT1, when analyzing the metal composition of the vacuole, significant $\mathrm{Mn}$ accumulation was reported in cells in which those two genes were expressed [60]. Moreover, two VIT homologs were located in the tonoplasts of wheat. Only one of them, TaVIT2, could supply an Mn-sensitive yeast strain with Mn. By overexpressing TaVIT1 by controlling an endosperm promoter, Mn content in wheat grains was significantly increased [61]. Although proteins in other plants such as pea or beans have not been fully examined, those plants or cultivars with homologous VIT families would probably prevent marsh spot symptoms from forming in their seeds.

The CAX family mainly regulates the influx of cations into the vacuole. Its members are metal transporters that arbitrate the influx of cations into the vacuole [62]. CAX2-like transporters of other species, such as tomato (Solanum lycopersicum) LeCAX2 and barley $\mathrm{HvCAX}_{V}$, transported $\mathrm{Ca}^{2+}$ and $\mathrm{Mn}^{2+}$ into yeast vacuoles upon heterologous expression, but with different transport kinetics [39]. $H v C A X 2$ was expressed ubiquitously in the roots, shoots, immature spikes, and seeds, preferentially in the embryo rather than in the endosperm of barley seeds [39].

Two NRAMP transporters, AtNRAMP3 and AtNRAMP4, occurred in the tonoplast of Arabidopsis [63]. Although the number of AtNRAMP3 and AtNRAMP4 proteins were not affected by a lack of $\mathrm{Mn}$, the expression of $A t$ NRAMP4 was induced under Fe-limited conditions [64]. In Arabidopsis leaf mesophyll cells with the nramp3 and nramp4 double mutants, Mn concentrations were similar to those in the wild-type plant cells, while an increased accumulation of $\mathrm{Mn}$ in the vacuoles was observed. In the case of an Mn deficiency, diminished growth was observed in the double mutant. This was correlated to reduced photosynthetic activity caused by a shortage of $\mathrm{Mn}$ for the formation of 
OEC complexes in PSII [43]. In addition, those two proteins also regulated the exportation of Mn from the leaf vacuoles to the seeds. Thus, the absence of $A t$ $N R A M P 3$ and AtNRAMP4 affected nutrient distribution in the leaves and uptake by seeds. Some transporters observed in seed subcellular components are shown in Figure 3.

\subsubsection{Quantitative Trait Loci (QTL) and Candidate Genes Associated with Marsh Spot Disease Resistance and Mn Deficiency}

The inheritance of marsh spot resistance in beans ( $P$. vulgaris) has rarely been reported. However, a recent genetic study of marsh spot resistance in cranberry common bean used joint segregation analysis of a biparental population of 138 recombinant inbred lines (RILs) derived from a cross between a resistant cultivar "Cran09" and a susceptible cultivar "Messina" [14]. The results based on 10 site-year showed that marsh spot ratings of disease incidence and severity were fairly stable and highly heritable with a high broad-sense heritability (>80\%). Resistance was controlled by four major genes with additive-epistasis effects [14].

Some major and minor QTL associated with Mn efficiency-related traits have been reported. With the help of inductively coupled plasma (ICP) spectrophotometry to measure Mn concentrations in common bean seeds, Blair, et al. [67] detected three QTL that were associated with Mn concentration. Leplat, et al. [68] performed chlorophyll a fluorescence analysis on 248 barley varieties, which were cultivated in six low Mn concentration fields for quantifying Mn deficiency.

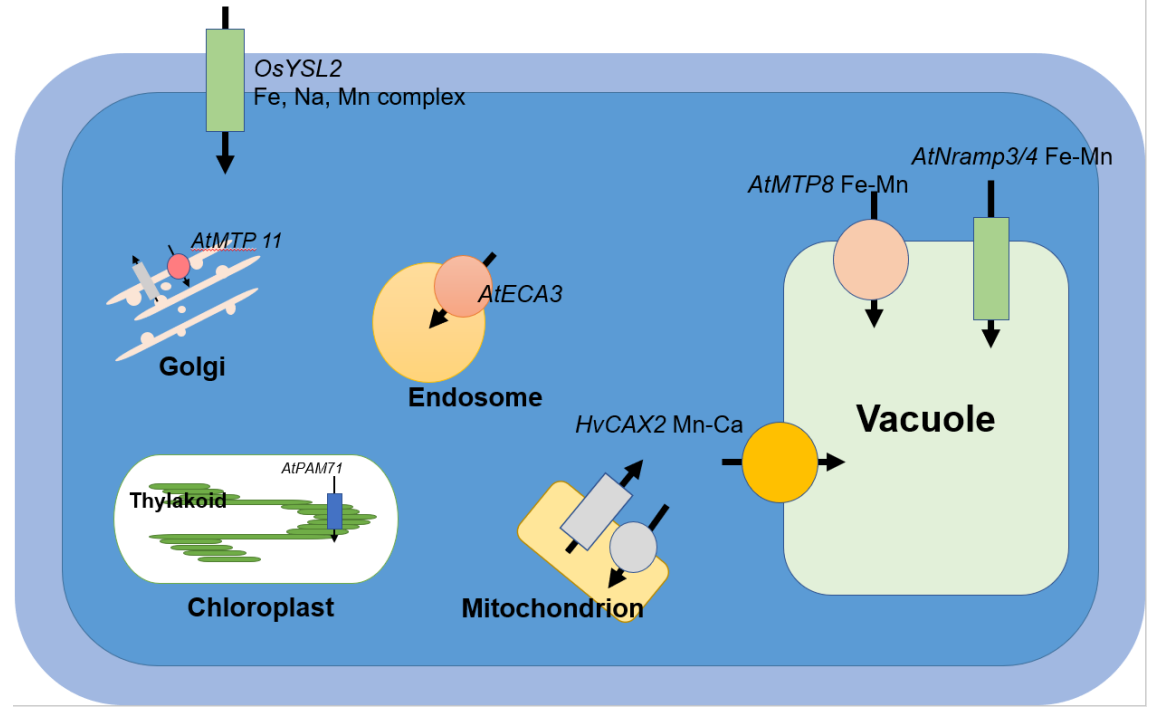

Figure 3. Subcellular components of Mn transport genes in plant seed cells. OsYSL2 participates in the Mn-Na complex from the apoplast to cytoplasm. Then, AtECA3 partitions $\mathrm{Mn}$ in the vesicles [65]. AtMTP8 and AtNRAMP3/4 are two transmembrane proteins, which are responsible for the import and export of $\mathrm{Mn}$ from the vacuole. Golgi secretes vesicles with the help of AtMTP11 [66]. AtPAM71 is an essential protein in the absorption of Mn by the thylakoid. Although Mn widely exists among subcellular components, some of the proteins (coloured in grey) involved in Mn transport are still unknown. 
Using the genome-wide association study (GWAS) they detected 54 QTL related to the generation of PSII subunit proteins, germin-like proteins, and Mn superoxide dismutase.

Most studies have focused on Mn accumulation in plant seeds. A total of six QTL that control Mn concentration in lentil (Lens culinaris) seeds were identified using linkage-based mapping of 120 lentil recombinant inbred lines (RILs); these major QTL explained 15\% - 24.1\% of Mn concentration variation [69]. Ten QTL for Mn concentration in canola (Brassica napus) seeds were detected, which were distributed across 8 chromosomes, and explained $9.1 \%-16.4 \%$ of the total variation [70]. In a study of Lotus japonicus, two QTL associated with Mn concentration explained $35.2 \%$ of the phenotypic variation and were identified on chromosomes 1 and 2 [71]. Using RILs derived from a cross of 93-11 with PA64s (with a high grain Mn concentration), one major QTL controlling Mn accumulation in rice grains was identified [72]. Some of the QTL mapping studies related to Mn efficiency are listed in Table 2.

Table 2. QTL loci and candidate genes related to Mn efficiency.

\begin{tabular}{|c|c|c|c|c|c|c|c|c|}
\hline Species & Trait & No. QTL & Chr & Material & Potential functional gene & Marker & Method & Reference \\
\hline $\begin{array}{l}\text { Phaseolus } \\
\text { vulgaris }\end{array}$ & Seed Mn con. & 3 & Chr $1,5,8$ & RILs & & SSR, RFLP & CIM & Blair, et al. [67] \\
\hline $\begin{array}{l}\text { Lotus } \\
\text { japonicus }\end{array}$ & Seed Mn con. & 2 & Chr 1,2 & RILs & & SSR, dCAPS & MQM & $\begin{array}{l}\text { Klein and } \\
\text { Grusak [71] }\end{array}$ \\
\hline $\begin{array}{l}\text { Brassica } \\
\text { napus }\end{array}$ & Seed Mn con. & 10 & $\begin{array}{l}\mathrm{A} 3, \mathrm{~A} 4, \mathrm{~A} 6 \\
\mathrm{~A} 10 \mathrm{C} 3, \mathrm{C} 8 \\
\mathrm{~A} 1, \mathrm{~A} 9, \mathrm{~A} 10\end{array}$ & RILs & $\begin{array}{l}C A X, U G P, I R T 1, N R A M P 5 \\
\text { and } A Z F 2\end{array}$ & SNP & CIM & Ding, et al. [70] \\
\hline Oryza sativa & $\begin{array}{l}\text { Seed Mn., Cd. } \\
\text { con. }\end{array}$ & $\begin{array}{l}11 \text { minor, } \\
1 \text { major }\end{array}$ & $\begin{array}{l}\text { Chr } 1 \text { - 10, } \\
\text { qGMN7.1 } \\
\text { on Chr } 7\end{array}$ & RILs, CSSL & OsNRAMP5 & $\begin{array}{l}\text { SNP, InDel, } \\
\text { SSR }\end{array}$ & IM & Liu, et al. [72] \\
\hline Oryza sativa & Seed Mn con. & 1 & Chr 4 & RILs & OsZIP3 & SSR & GLM, MLM & Nawaz, et al. [73] \\
\hline Brassica rapa & Leave Mn con. & 2 & Chr 5,6 & $\mathrm{DH}$ & & $\begin{array}{l}\text { AFLP, SRAP, } \\
\text { ESTP }\end{array}$ & MQM, IM & Wu, et al. [74] \\
\hline $\begin{array}{l}\text { Hordeum } \\
\text { vulgare }\end{array}$ & $\begin{array}{l}\text { Chl a fluor., } \\
\text { leave Mn con. }\end{array}$ & $\begin{array}{l}54 \text { (Chl a } \\
\text { fluor.), } 4 \\
\text { leave } \mathrm{Mn} \\
\text { con.) }\end{array}$ & Chr $2-7$ & $\begin{array}{l}248 \text { Barely } \\
\text { varieties }\end{array}$ & $\begin{array}{l}A K 368229, M L O C \_18354.1, \\
M L O C \_38362.2, A K 368229, \\
M L O C \_18354.1(\mathrm{Chl} \mathrm{a/b} \\
\text { binding); } M L O C \_75098.2, \\
A K 367749 \text { (Mn binding); } \\
M L O C \_3173.4, A K 374059, \\
A K 357955 \text { (PP2C); } \\
M L O C \_40094.1 \text { (PSI); } \\
\text { AK251925.1, MLOC_82113.1, } \\
A K 249774.1, M L O C \_77860.1, \\
A K 369292 \text { (PSII) }\end{array}$ & SNP & MLM & Leplat, et al. [68] \\
\hline
\end{tabular}

Mn con.: Mn concentration; Cd con.: Cd concentration; fluor.: fluorescence; P: phosphorus concentration; CSSL: chromosome segment substitution line; SNP: single nucleotide polymorphism; AFLP: Amplified fragment length polymorphism; SSR: simple sequence repeat; SRAP: sequence-related amplified polymorphism; ESTP: expressed sequence tagged polymorphism; dCAPS: derived cleaved amplified polymorphic sequence; InDel: insertion and deletion sequence; IM: Interval mapping; CIM: Composite interval mapping; MLM: Mixed linear model; GLM: Generalized linear model; MQM: Multiple QTL mapping. 


\section{Conclusion and Perspective}

The causal link between the marsh spot and the Mn deficiency has been known for more than half a century. Mn availability can be a seriously limiting factor for plant growth, which necessitates the operation of high-affinity transporters in the roots along with efficient mechanisms for distribution in the plant to cope with $\mathrm{Mn}$ shortages. Crops with improved Mn uptake capacity and use efficiency will provide sufficient $\mathrm{Mn}$ for PSII, increasing their photosynthetic efficiency and consequently achieving better growth and higher yield. The function, regulation, and cooperation of $\mathrm{Mn}^{2+}$ transport proteins in different plant tissues exposed to an Mn deficiency or excess should be understood at a transcriptional and a protein level. Such studies will eventually elucidate the mechanisms controlling Mn acquisition, subcellular compartmentation, and homeostasis in plants, a knowledge that can be harnessed to develop Mn-efficient germplasm of the staple crops. In modern plant breeding, molecular markers are often used for crop improvement. Researchers construct special genetic populations to identify the QTL associated with traits of agronomic importance. Those identified QTL further assist breeders in developing better cultivars with high resistance to diseases such as marsh spot. This review on marsh spot and its causal factor, $\mathrm{Mn}$ deficiency, may help to further identify and validate QTL in plants, especially common beans. High accuracy and confidence in cultivar selection based on related QTLs will profoundly reduce breeding costs and enrich quantitative agronomic traits. Since Mn deficiency is a worldwide issue, highly resistant cultivars would significantly improve the yield and seed quality of the crops.

\section{Acknowledgements}

The authors gratefully acknowledge the financial support provided by the Manitoba Pulse and Soybean Growers, Agriculture and Agri-Food Canada, the Canadian Agricultural Partnership Pulse Science Cluster and the Discovery Grant from Natural Science and Engineering Research Council of Canada.

\section{Conflicts of Interest}

The authors declare no conflicts of interest regarding the publication of this paper.

\section{References}

[1] Henkens, C.H. (1958) The Prevention of Marsh Spot in Peas by Spraying with Manganese Sulphate. Landbouwvoorlichting, 15, 262-265.

[2] Reynolds, J.D. (1955) Marsh Spot of Peas: A Review of Present Knowledge. Journal of the Science of Food and Agriculture, 6, 725-734. https://doi.org/10.1002/jsfa.2740061201

[3] Piper, C.S. (1941) Marsh Spot of Peas: A Manganese Deficiency Disease. The Journal of Agricultural Science, 31, 448-453.

https://doi.org/10.1017/S0021859600049637 
[4] Heintze, S.G. (1938) Readily Soluble Manganese of Soils and Marsh Spot of Peas. The Journal of Agricultural Science, 28, 175-186. https://doi.org/10.1017/S0021859600050590

[5] Lacey, M.S. (1934) Studies in Bacteriosis: Xxi. An Investigation of Marsh Spot of Peas: With a Note on the Morphological Structure. Annals of Applied Biology, 21, 621-640. https://doi.org/10.1111/j.1744-7348.1934.tb07465.x

[6] Biddle, A.J. and Cattlin, N.D. (2007) Pests, Diseases, and Disorders of Peas and Beans: A Colour Handbook. CRC Press, London. https://doi.org/10.1201/b15137

[7] Howard, R.J., Garland, J.A. and Seaman, W.L. (1994) Diseases and Pests of Vegetable Crops in Canada. Canadian Phytopathological Society, Ottawa.

[8] Hewitt, E.J. (1945) 'Marsh Spot' in Beans. Nature, 155, 22-23. https://doi.org/10.1038/155022b0

[9] De Bruyn, H.L.G. (1933) Kwade Harten van de Erwten. Tijdschrift Over Plantenziekten, 39, 281-318. https://doi.org/10.1007/BF02807372

[10] Maillard, A., Diquelou, S., Billard, V., Laine, P., Garnica, M., Prudent, M., Garcia-Mina, J.M., Yvin, J.C. and Ourry, A. (2015) Leaf Mineral Nutrient Remobilization during Leaf Senescence and Modulation by Nutrient Deficiency. Frontiers in Plant Science, 6, Article No. 317. https://doi.org/10.3389/fpls.2015.00317

[11] Graham, R.D., Hannam, R.J. and Uren, N.C. (1988) Manganese in Soils and Plants. Vol. 33, Springer, Dordrecht. https://doi.org/10.1007/978-94-009-2817-6

[12] Furneaux, B.S. and Glasscock, H.H. (1936) Soils in Relation to Marsh Spot of Pea Seed. The Journal of Agricultural Science, 26, 59-84. https://doi.org/10.1017/S0021859600021808

[13] De Bruyn, H.L.G. (1939) Mn-Deficiency as the Cause of Marsh Spot of Pea Seeds. Tijdschrift Over Plantenziekten, 45, 106-120. https://doi.org/10.1007/BF02651193

[14] Jia, B., Conner, R.L., Khan, N., Hou, A., Xia, X. and You, F.M. (2021) Inheritance of Marsh Spot Disease Resistance in Cranberry Common Bean (Phaseolus vulgaris L.). The Crop Journal. (In Press) https://doi.org/10.1016/j.cj.2021.05.013

[15] Pethybridge, G.H. (1936) Marsh Spot in Pea Seeds: Is It a Deficiency Disease. Journal of the Ministry of Agriculture, 43, 55-58.

[16] Samuel, G. and Piper, C.S. (1929) Manganese as an Essential Element for Plant Growth. Annals of Applied Biology, 16, 493-524. https://doi.org/10.1111/j.1744-7348.1929.tb07630.x

[17] Moraghan, J. and Grafton, G. (2000) 'Marsh Spot' in Cranberry Bean Seed. Annual Report of the Bean Improvement Cooperative, 43, 9-10.

[18] Koopman, C. (1937) Invloed van mangaansulfaatbespuiting tegen kwaadhartigheid bij schokkererwten. Tijdschr Over Plantenziekten, 43, 64-66. https://doi.org/10.1007/BF01988574

[19] Lewis, A.H. (1939) Manganese Deficiencies in Crops. I. Spraying Pea Crops with Solutions of Manganese Salts to Eliminate Marsh-Spot. Empire Journal of Experimental Agriculture, 7, 150-154.

[20] Hoecker, N., Leister, D. and Schneider, A. (2017) Plants Contain Small Families of UPF0016 Proteins Including the PHOTOSYNTHESIS AFFECTED MUTANT71 Transporter. Plant Signaling \& Behavior, 12, Article No. e1278101. https://doi.org/10.1080/15592324.2016.1278101

[21] Dasgupta, J., Ananyev, G.M. and Dismukes, G.C. (2008) Photoassembly of the Water-Oxidizing Complex in Photosystem II. Coordination Chemistry Reviews, 252, 
347-360. https://doi.org/10.1016/j.ccr.2007.08.022

[22] Foyer, C.H. and Noctor, G. (2003) Redox Sensing and Signalling Associated with Reactive Oxygen in Chloroplasts, Peroxisomes and Mitochondria. Physiologia Plantarum, 119, 355-364. https://doi.org/10.1034/j.1399-3054.2003.00223.x

[23] Gutteridge, J.M.C. and Halliwell, B. (2010) Antioxidants: Molecules, Medicines, and Myths. Biochemical and Biophysical Research Communications, 393, 561-564. https://doi.org/10.1016/j.bbrc.2010.02.071

[24] Schmidt, S.B., Jensen, P.E. and Husted, S. (2016) Manganese Deficiency in Plants: The Impact on Photosystem II. Trends in Plant Science, 21, 622-632. https://doi.org/10.1016/j.tplants.2016.03.001

[25] Broadley, M., Brown, P., Cakmak, I., Rengel, Z. and Zhao, F.-J. (2012) Function of Nutrients. In: Marschner, H., Ed., Marschner's Mineral Nutrition of Higher Plants, Academic Press, Oxford, 191-248. https://doi.org/10.1016/B978-0-12-384905-2.00007-8

[26] Engelsma, G. (1972) A Possible Role of Divalent Manganese Ions in the Photoinduction of Phenylalanine Ammonia-Lyase. Plant Physiology, 50, 599-602.

https://doi.org/10.1104/pp.50.5.599

[27] Hebbern, C.A., Laursen, K.H., Ladegaard, A.H., Schmidt, S.B., Pedas, P., Bruhn, D., Schjoerring, J.K., Wulfsohn, D. and Husted, S. (2009) Latent Manganese Deficiency Increases Transpiration in Barley (Hordeum vulgare). Plant Physiology, 135, 307-316. https://doi.org/10.1111/j.1399-3054.2008.01188.x

[28] Rohdich, F., Lauw, S., Kaiser, J., Feicht, R., Köhler, P., Bacher, A. and Eisenreich, W. (2006) Isoprenoid Biosynthesis in Plants 2C-methyl-d-erythritol-4-phosphate Synthase (IspC Protein) of Arabidopsis thaliana. The FEBS Journal, 273, 4446-4458. https://doi.org/10.1111/j.1742-4658.2006.05446.x

[29] Ohki, K., Boswell, F.C., Parker, M.B., Shuman, L.M. and Wilson, D.O. (1979) Critical Manganese Deficiency Level of Soybean Related to Leaf Position. Agronomy Journal, 71, 233-234. https://doi.org/10.2134/agronj1979.00021962007100020004x

[30] Shenker, M., Plessner, O.E. and Tel-Or, E. (2004) Manganese Nutrition Effects on Tomato Growth, Chlorophyll Concentration, and Superoxide Dismutase Activity. Journal of Plant Physiology, 161, 197-202. https://doi.org/10.1078/0176-1617-00931

[31] Chu, H.-H., Car, S., Socha, A.L., Hindt, M.N., Punshon, T. and Guerinot, M.L. (2017) The Arabidopsis MTP8 Transporter Determines the Localization of Manganese and Iron in Seeds. Scientific Reports, 7, Article No. 11024. https://doi.org/10.1038/s41598-017-11250-9

[32] Giles, C.D., Brown, L.K., Adu, M.O., Mezeli, M.M., Sandral, G.A., Simpson, R.J., Wendler, R., Shand, C.A., Menezes-Blackburn, D., Darch, T., Stutter, M.I., Lumsdon, D.G., Zhang, H., Blackwell, M.S., Wearing, C., Cooper, P., Haygarth, P.M. and George, T.S. (2017) Response-Based Selection of Barley Cultivars and Legume Species for Complementarity: Root Morphology and Exudation in Relation to Nutrient Source. Plant Science, 255, 12-28. https://doi.org/10.1016/j.plantsci.2016.11.002

[33] Guerinot, M.L. (2000) The ZIP Family of Metal Transporters. Biochimica et Biophysica Acta (BBA)-Biomembranes, 1465, 190-198. https://doi.org/10.1016/S0005-2736(00)00138-3

[34] Kolaj-Robin, O., Russell, D., Hayes, K.A., Pembroke, J.T. and Soulimane, T. (2015) Cation Diffusion Facilitator Family: Structure and Function. FEBS Letters, 589, 1283-1295. https://doi.org/10.1016/j.febslet.2015.04.007

[35] Renfrew, A.K., O’Neill, E.S., Hambley, T.W. and New, E.J. (2018) Harnessing the 
Properties of Cobalt Coordination Complexes for Biological Application. Coordination Chemistry Reviews, 375, 221-233. https://doi.org/10.1016/j.ccr.2017.11.027

[36] Montanini, B., Blaudez, D., Jeandroz, S., Sanders, D. and Chalot, M. (2007) Phylogenetic and Functional Analysis of the Cation Diffusion Facilitator (CDF) Family: Improved Signature and Prediction of Substrate Specificity. BMC Genomics, 8, Article No. 107. https://doi.org/10.1186/1471-2164-8-107

[37] Pittman, J.K. and Hirschi, K.D. (2016) Phylogenetic Analysis and Protein Structure Modelling Identifies Distinct $\mathrm{Ca}^{2+} /$ Cation Antiporters and Conservation of Gene Family Structure within Arabidopsis and Rice Species. Rice, 9, Article No. 3. https://doi.org/10.1186/s12284-016-0075-8

[38] Cao, J. (2019) Molecular Evolution of the Vacuolar Iron Transporter (VIT) Family Genes in 14 Plant Species. Genes, 10, Article No. 144. https://doi.org/10.3390/genes10020144

[39] Edmond, C., Shigaki, T., Ewert, S., Nelson, M.D., Connorton, J.M., Chalova, V., Noordally, Z. and Pittman, J.K. (2009) Comparative Analysis of CAX2-Like Cation Transporters Indicates Functional and Regulatory Diversity. Biochemical Journal, 418, 145-154. https://doi.org/10.1042/BJ20081814

[40] Kamiya, T., Akahori, T., Ashikari, M. and Maeshima, M. (2006) Expression of the Vacuolar $\mathrm{Ca}^{2+} / \mathrm{H}^{+}$Exchanger, OSCAX1a, in Rice: Cell and Age Specificity of Expression, and Enhancement by $\mathrm{Ca}^{2+}$. Plant and Cell Physiology, 47, 96-106. https://doi.org/10.1093/pcp/pci227

[41] Eroglu, S., Meier, B., von Wirén, N. and Peiter, E. (2016) The Vacuolar Manganese Transporter mtp8 Determines Tolerance to Iron Deficiency-Induced Chlorosis in Arabidopsis. Plant Physiology, 170, 1030-1045. https://doi.org/10.1104/pp.15.01194

[42] Thomine, S., Wang, R., Ward, J.M., Crawford, N.M. and Schroeder, J.I. (2000) Cadmium and Iron Transport by Members of a Plant Metal Transporter Family in Arabidopsis with Homology to Nramp Genes. Proceedings of the National Academy of Sciences of the United States of America, 97, 4991-4996.

https://doi.org/10.1073/pnas.97.9.4991

[43] Lanquar, V., Ramos, M.S., Lelièvre, F., Barbier-Brygoo, H., Krieger-Liszkay, A., Krämer, U. and Thomine, S. (2010) Export of Vacuolar Manganese by AtNRAMP3 and AtNRAMP4 Is Required for Optimal Photosynthesis and Growth under Manganese Deficiency. Plant Physiology, 152, 1986-1999. https://doi.org/10.1104/pp.109.150946

[44] Koike, S., Inoue, H., Mizuno, D., Takahashi, M., Nakanishi, H., Mori, S. and Nishizawa, N.K. (2004) OsYSL2 Is a Rice Metal-Nicotianamine Transporter That Is Regulated by Iron and Expressed in the Phloem. The Plant Journal, 39, 415-424. https://doi.org/10.1111/j.1365-313X.2004.02146.x

[45] Pedas, P., Ytting, C.K., Fuglsang, A.T., Jahn, T.P., Schjoerring, J.K. and Husted, S. (2008) Manganese Efficiency in Barley: Identification and Characterization of the Metal Ion Transporter HvIRT1. Plant Physiology, 148, 455-466. https://doi.org/10.1104/pp.108.118851

[46] Marschner, H. (1995) Mineral Nutrition of Higher Plants. 2nd Edition, Academic Press, London, 233-234.

[47] Eugene, V.M., David, P.M. and Benjamin, J.M. (1968) Manganese Absorption by Excised Barley Roots. Plant Physiology, 43, 527-530. https://doi.org/10.1104/pp.43.4.527

[48] Humphries, J., Stangoulis, J. and Graham, R. (2007) Manganese. In: Barker, A.V. 
and Pilbeam, D.J., Eds., Handbook of Plant Nutrition, Taylor and Francis, Boca Raton, 351-366.

https://www.worldcat.org/title/handbook-of-plant-nutrition/oclc/65205150

[49] Waters, B.M. and Sankaran, R.P. (2011) Moving Micronutrients from the Soil to the Seeds: Genes and Physiological Processes from a Biofortification Perspective. Plant Science, 180, 562-574. https://doi.org/10.1016/j.plantsci.2010.12.003

[50] Sasaki, A., Yamaji, N., Yokosho, K. and Ma, J.F. (2012) Nramp5 Is a Major Transporter Responsible for Manganese and Cadmium Uptake in Rice. Plant Cell, 24, 2155-2167. https://doi.org/10.1105/tpc.112.096925

[51] Curie, C., Alonso, J.M., Le Jean, M., Ecker, J.R. and Briat, J.F. (2000) Involvement of NRAMP1 from Arabidopsis thaliana in Iron Transport. Biochemical Journal, 347, 749-755. https://doi.org/10.1042/bj3470749

[52] Shao, J.F., Yamaji, N., Shen, R.F. and Ma, J.F. (2017) The Key to Mn Homeostasis in Plants: Regulation of Mn Transporters. Trends in Plant Science, 22, 215-224. https://doi.org/10.1016/j.tplants.2016.12.005

[53] Cailliatte, R., Schikora, A., Briat, J.-F., Mari, S. and Curie, C. (2010) High-Affinity Manganese Uptake by the Metal Transporter Nramp1 Is Essential for Arabidopsis Growth in Low Manganese Conditions. Plant Cell, 22, 904-917. https://doi.org/10.1105/tpc.109.073023

[54] Wu, D., Yamaji, N., Yamane, M., Kashino-Fujii, M., Sato, K. and Feng Ma, J. (2016) The HvNramp5 Transporter Mediates Uptake of Cadmium and Manganese, but Not Iron. Plant Physiology, 172, 1899-1910. https://doi.org/10.1104/pp.16.01189

[55] Rieuwerts, J.S., Thornton, I., Farago, M.E. and Ashmore, M.R. (1998) Factors Influencing Metal Bioavailability in Soils: Preliminary Investigations for the Development of a critical loads approach for metals. Chemical Speciation \& Bioavailability, 10, 61-75. https://doi.org/10.3184/095422998782775835

[56] Yamaji, N., Sasaki, A., Xia, J.X., Yokosho, K. and Ma, J.F. (2013) A Node-Based Switch for Preferential Distribution of Manganese in Rice. Nature Communications, 4, Article No. 2442. https://doi.org/10.1038/ncomms3442

[57] Ueno, D., Sasaki, A., Yamaji, N., Miyaji, T., Fujii, Y., Takemoto, Y., Moriyama, S., Che, J., Moriyama, Y., Iwasaki, K. and Ma, J.F. (2015) A Polarly Localized Transporter for Efficient Manganese Uptake in Rice. Nature Plants, 1, Article No. 15170. https://doi.org/10.1038/nplants.2015.170

[58] Waters, B.M., Chu, H.-H., DiDonato, R.J., Roberts, L.A., Eisley, R.B., Lahner, B., Salt, D.E. and Walker, E.L. (2006) Mutations in Arabidopsis Yellow Stripe-Like1 and Yellow Stripe-Like3 Reveal Their Roles in Metal Ion Homeostasis and Loading of Metal Ions in Seeds. Plant Physiology, 141, 1446-1458.

https://doi.org/10.1104/pp.106.082586

[59] Milner, M.J., Seamon, J., Craft, E. and Kochian, L.V. (2013) Transport Properties of Members of the ZIP Family in Plants and Their Role in $\mathrm{Zn}$ and Mn Homeostasis. Journal of Experimental Botany, 64, 369-381. https://doi.org/10.1093/jxb/ers315

[60] Zhang, Y., Xu, Y.-H., Yi, H.-Y. and Gong, J.-M. (2012) Vacuolar Membrane Transporters OsVIT1 and OsVIT2 Modulate Iron Translocation between Flag Leaves and Seeds in Rice. The Plant Journal, 72, 400-410.

https://doi.org/10.1111/j.1365-313X.2012.05088.x

[61] Connorton, J.M., Jones, E.R., Rodríguez-Ramiro, I., Fairweather-Tait, S., Uauy, C. and Balk, J. (2017) Wheat Vacuolar Iron Transporter TaVIT2 Transports Fe and Mn and Is Effective for Biofortification. Plant Physiology, 174, 2434-2444. 
https://doi.org/10.1104/pp.17.00672

[62] Enrico, M., Stefan, M., Alexis, D.A. and Réka, N. (2012) Vacuolar Transporters in Their Physiological Context. Annual Review of Plant Biology, 63, 183-213. https://doi.org/10.1146/annurev-arplant-042811-105608

[63] Thomine, S., Lelièvre, F., Debarbieux, E., Schroeder, J.I. and Barbier-Brygoo, H. (2003) AtNRAMP3, a Multispecific Vacuolar Metal Transporter Involved in Plant Responses to Iron Deficiency. The Plant Journal, 34, 685-695. https://doi.org/10.1046/j.1365-313X.2003.01760.x

[64] Lanquar, V., Lelièvre, F., Bolte, S., Hamès, C., Alcon, C., Neumann, D., Vansuyt, G., Curie, C., Schröder, A., Krämer, U., Barbier-Brygoo, H. and Thomine, S. (2005) Mobilization of Vacuolar Iron by AtNRAMP3 and AtNRAMP4 Is Essential for Seed Germination on Low Iron. The EMBO Journal, 24, 4041-4051. https://doi.org/10.1038/sj.emboj.7600864

[65] Mills, R.F., Doherty, M.L., López-Marqués, R.L., Weimar, T., Dupree, P., Palmgren, M.G., Pittman, J.K. and Williams, L.E. (2008) ECA3, a Golgi-Localized $\mathrm{P}_{2 \mathrm{~A}}$-Type ATPase, Plays a Crucial Role in Manganese Nutrition in Arabidopsis. Plant Physiology, 146, 116-128. https://doi.org/10.1104/pp.107.110817

[66] Delhaize, E., Gruber, B.D., Pittman, J.K., White, R.G., Leung, H., Miao, Y., Jiang, L., Ryan, P.R. and Richardson, A.E. (2007) A Role for the AtMTP11 Gene of Arabidopsis in Manganese Transport and Tolerance. The Plant Journal, 51, 198-210. https://doi.org/10.1111/j.1365-313X.2007.03138.x

[67] Blair, M.W., Wu, X., Bhandari, D. and Astudillo, C. (2016) Genetic Dissection of ICP-Detected Nutrient Accumulation in the Whole Seed of Common Bean (Phaseolus vulgaris L.). Frontiers in Plant Science, 7, Article No. 219. https://doi.org/10.3389/fpls.2016.00219

[68] Leplat, F., Pedas, P.R., Rasmussen, S.K. and Husted, S. (2016) Identification of Manganese Efficiency Candidate Genes in Winter Barley (Hordeum vulgare) Using Genome Wide Association Mapping. BMC Genomics, 17, Article No. 775. https://doi.org/10.1186/s12864-016-3165-5

[69] Ates, D., Aldemir, S., Yagmur, B., Kahraman, A., Ozkan, H., Vandenberg, A. and Tanyolac, M.B. (2018) QTL Mapping of Genome Regions Controlling Manganese Uptake in Lentil Seed. G3: Genes|Genomes|Genetics, 8, 1409-1416. https://doi.org/10.1534/g3.118.200259

[70] Ding, G., Yang, M., Hu, Y., Liao, Y., Shi, L., Xu, F. and Meng, J. (2010) Quantitative Trait loci Affecting Seed Mineral Concentrations in Brassica napus Grown with Contrasting Phosphorus Supplies. Annals of Botany, 105, 1221-1234. https://doi.org/10.1093/aob/mcq050

[71] Klein, M.A. and Grusak, M.A. (2009) Identification of Nutrient and Physical Seed Trait QTL in the Model Legume Lotus japonicus. Genome, 52, 677-691. https://doi.org/10.1139/G09-039

[72] Liu, C., Chen, G., Li, Y., Peng, Y., Zhang, A., Hong, K., Jiang, H., Ruan, B., Zhang, B., Yang, S., Gao, Z. and Qian, Q. (2017) Characterization of a Major QTL for Manganese Accumulation in Rice Grain. Scientific Reports, 7, Article No. 17704. https://doi.org/10.1038/s41598-017-18090-7

[73] Nawaz, Z., Kakar, K.U., Li, X.-B., Li, S., Zhang, B., Shou, H.-X. and Shu, Q.-Y. (2015) Genome-Wide Association Mapping of Quantitative Trait Loci (QTLs) for Contents of Eight Elements in Brown Rice (Oryza sativa L.). Journal of Agricultural and Food Chemistry, 63, 8008-8016. https://doi.org/10.1021/acs.jafc.5b01191 
[74] Wu, J., Yuan, Y.-X., Zhang, X.-W., Zhao, J., Song, X., Li, Y., Li, X., Sun, R., Koornneef, M., Aarts, M.G.M. and Wang, X.-W. (2008) Mapping QTLs for Mineral Accumulation and Shoot Dry Biomass under Different Zn Nutritional Conditions in Chinese Cabbage (Brassica rapa L. ssp. Pekinensis). Plant and Soil, 310, 25-40. https://doi.org/10.1007/s11104-008-9625-1 